\title{
Medycyna w działalności i pismach alchemika Michała Sędziwoja (1566-1636)
}

Słowa kluczowe: alchemia; medycyna wczesnonowożytna; Sędziwój; Paracelsus; Croll

Alchemia bywa zwykle kojarzona z próbami przemiany metali nieszlachetnych w złoto, naiwnymi, chaotycznymi i opartymi na niejasnych przesłankach mistyczno-witalistycznej wizji przyrody. Tymczasem - jak pokazują badania historyków alchemii, szczególnie ostatniego ćwierćwiecza - dociekania alchemików miały o wiele głębszy wymiar. Odwołując się do różnych nurtów filozofii przyrody, w różnych epokach i kręgach cywilizacyjnych, autorzy traktatów alchemicznych konstruowali bardzo zróżnicowane i często wyrafinowane teorie budowy materii, zasad kierujących jej przemianami, a nawet funkcjonowania całego wszechświata. Znakomita większość owych autorów wywodziła swe rozważania i spekulacje z praktycznej znajomości procesów chemicznych, choć oczywiście interpretowanych w kategoriach dominujących w danym okresie światopoglądów i wiedzy rzemieślniczej². We wczesnonowożytnej Europie wykształciło się wiele prądów ideowych i nurtów praktycznego badania materii, które dziś określa się

\footnotetext{
${ }^{1}$ Katedra Ekonomiki Turystyki i Informatyki, Akademia Wychowania Fizycznego im. E. Piaseckiego w Poznaniu, e-mail: prinke@awf.poznan.pl, ORCID: 0000-00021082-6741.

${ }^{2}$ Znakomitą syntezą najnowszego stanu badań w tym zakresie jest: L.M. Principe, The secrets of alchemy, Chicago 2012.
} 
wspólnym mianem alchemii, mimo ich wewnętrznego zróżnicowania. Obok racjonalnych dociekań, czerpiących z wcześniejszych tradycji scholastycznych, wzbogaconych o wiedzę eksperymentalną z pierwszej ręki, bardzo silny był w alchemii nurt mistyczno-hermetyczny, a także literacko-emblematyczny ${ }^{3}$. Wprowadzenie przez Paracelsusa leków chemicznych do praktyki medycznej znacząco wzmocniło luźne wcześniej związki alchemii z farmacją. Choć sam Paracelsus był zdecydowanym przeciwnikiem poszukiwania metod transmutacji metali, jego zwolennicy i następcy przypisali mu autorstwo szeregu traktatów na ten właśnie temat, tak że wkrótce wielu lekarzy chymiatrów podejmowało próby przemieniania metali nieszlachetnych w złoto i publikowało traktaty o Kamieniu Filozofów, a wielu tradycyjnych alchemików bez wykształcenia medycznego zajmowało się leczeniem. Do tej drugiej grupy zaliczał się również najważniejszy polski alchemik Michał Sędziwój (1566-1636), szeroko znany na świecie pod zlatynizowaną formą imienia i nazwiska Michael Sendivogius, a niniejszy artykuł stanowi próbę zebrania nielicznych i rozproszonych wzmianek źródłowych na temat jego praktyki medycznej4.

Sędziwój urodził się najprawdopodobniej w 1566 r., ale istnieją poważne wątpliwości co do jego pochodzenia. Mając już ponad 30 lat, dowodził na różne sposoby (również sądownie), że jest członkiem szlacheckiej rodziny Sędzimirów z powiatu sądeckiego, ale intensywna kwerenda genealogiczna wykluczyła taką możliwośćs. Być może był dzieckiem nieślubnym jakiejś wysoko postawionej osobistości, co zarzucano mu później w Pradze, a co mogłoby też tłumaczyć jego niezwykłą karierę na dwóch dworach najpotężniejszych władców Europy środkowej: Rudolfa II i Zygmunta III Wazy. Zapewne ów zamożny ojciec, nie mogąc przekazać mu majątku ziemskiego, wysłał go najpierw na studia (które odbył na kilku uniwersytetach), a następnie zaprotegował w Pradze, gdzie w 1594 r. Sędziwój został przyjęty w po-

\footnotetext{
${ }^{3}$ Różnorodność nurtów w tekstach alchemicznych na przestrzeni wieków omawia szczegółowo: R.T. Prinke, Zwodniczy ogród błędów. Piśmiennictwo alchemiczne do końca XVIII wieku, Warszawa 2014.

${ }^{4}$ Podstawową monografią na jego temat pozostaje nadal: R. Bugaj, Michał Sędziwój (1566-1636). Życie i pisma, Wrocław 1968; późniejsza monografia, koncentrująca się na roli Sędziwoja w odkryciu tlenu, to: Z. Szydło, Woda, która nie moczy rak. Alchemia Michała Sedziwoja, tłum. R. Mierzecki, Warszawa 1997; autorami ważnych artykułów byli m.in. Włodzimierz Hubicki, Paulo Alves Porto, Didier Kahn i piszący te słowa.

${ }^{5}$ R.T. Prinke, Beyond patronage: Michael Sendivogius and the meanings of success in alchemy, [w:] Chymia: Science and nature in medieval and early modern Europe, $\mathrm{M}$. López Pérez, D. Kahn, M.R. Bueno (red.), Newcastle upon Tyne 2010, s. 175-231; tenże, Michał Sędziwój - poczatki kariery, „Kwartalnik Historii Nauki i Techniki” 2012, nr 1, s. $89-129$.
} 
czet dworzan cesarskich ${ }^{6}$. Funkcję tę - bez szczególnych obowiązków - utrzymał przynajmniej do 1612 r., a jednocześnie w roku 1600 został mianowany sekretarzem królewskim przez króla polskiego ${ }^{7}$. W latach 1606-1626 mieszkał w Polsce, najpierw w Krzepicach u Mikołaja Wolskiego, a następnie w Krakowie, w dworku za bramą św. Anny, czyli po drugiej stronie muru od Collegium Maius ${ }^{8}$. Dwór ten później sprzedał i kupił dwie kamienice w mieście, ale zaraz wyjechał znów do Pragi, gdzie został radcą cesarza Ferdynanda II. Za świadczone usługi otrzymał w 1630 r. majątek Kravaře z małym zamkiem i kamienicę w Ołomuńcu. Zmarł sześć lat później i zapewne został pochowany w kościele minoryckim św. Ducha w Opawie 9 .

Jak wiadomo z korespondencji Sędziwoja do Rudolfa II, alchemią interesował się już przynajmniej od początku lat 90. XVI w. i uchodził za posiadacza Kamienia Filozofów ${ }^{10}$. W 1604 r. ukazało się w Pradze pierwsze wydanie książki De lapide philosophorum tractatus duodecim, napisanej prawdopodobnie pod naciskiem cesarza i wydanej z jego inicjatywy, które to dzieło przyniosło autorowi olbrzymią sławę w całej Europie i Ameryce Północnej ${ }^{11}$. Do końca XVIII w. miało wraz z dwoma kolejnymi tekstami Sędziwoja, Dialogus Mercurii, alchymistae et Naturae oraz Tractatus de sulphure, wydawanych później wspólnie jako Novym lumen chymicum - ok. 60 wydań, w tym tłumaczeń na francuski, niemiecki, holenderski, angielski i rosyjski

${ }^{6}$ Der Hof Kaiser Rudolfs II. Eine Editition der Hofstaatsverzeichnisse 1576-1612, wyd. J. Hausenblasová, Praha 2002, s. 276-277.

7 R.T. Prinke, A. Pawlaczyk, Dwa listy Zygmunta III Wazy do cesarza Rudolfa II w sprawie alchemika Michała Sędziwoja, „Pamiętnik Biblioteki Kórnickiej” 2005, s. 127-134; R.T. Prinke, Tajna misja alchemika Sędziwoja. Epizod z pogranicza dziejów nauki, polityki i wojskowości, [w:] Historia na źródłach oparta. Studia ofiarowane Profesorowi Tadeuszowi Srogoszowi w 65. rocznicę urodzin, A. Stroynowski (red.), Częstochowa 2017, s. 531-550.

${ }^{8}$ R.T. Prinke, K. Follprecht, The court at St. Anne's Gate. New sources on the Cracovian period in the biography of Michael Sendivogius (1566-1636), [w:] Światto i ciemność. Imaginatio. Tom 8, M. Rzeczycka, A. Świerzowska, I. Trzcińska (red.), Gdańsk 2017, s. 43-66.

${ }^{9}$ R.T. Prinke, Nolite de me inquirere (Nechtyějte se po mniě ptatj): Michael Sendivogius (1566-1636), [w:] Alchymie a Rudolf II. Hledání tajemství přirody ve střední Evropě v 16. a 17. století, I. Purš, V. Karpenko (red.), Praha 2011, s. 317-333; identyfikację tego domu w Ołomuńcu podaje: tenże, New light on Michael Sendivogius' writings: The treatises written in Prague and maybe in Olomouc, [w:] Latin alchemical literature of Czech provenance, T. Nejeschleba, J. Michalík (red.), Olomouc 2015, s. 131-147.

${ }^{10}$ R.T. Prinke, M.A. Zuber, Alchemical Patronage and the Making of an Adept: Letters of Michael Sendivogius to Emperor Rudolf II and His Chamberlain Hans Popp, „Ambix” 2018, nr 4, s. 217-243.

${ }^{11}$ R.T. Prinke, New light on the alchemical writings of Michael Sendivogius (15661636), „Ambix” 2016, nr 3, s. 217-243. 
(nie licząc tłumaczeń na inne języki zachowanych w rękopisach) ${ }^{12}$. Żaden inny polski autor wczesnonowożytny nie stworzył tak popularnego dzieła, a wpływem na innych uczonych Sędziwój ustępuje jedynie Kopernikowi. Trudno wręcz znaleźć późniejsze publikacje alchemiczno-chemiczne, które by nie cytowały polskiego alchemika wprost albo nie powtarzały jego idei. Wystarczy wspomnieć, że Isaac Newton miał w swoim księgozbiorze kilka wydań dzieł Sędziwoja, na których nanosił swoje uwagi, a zachowały się także jego wypisy z tychże dzieł z własnymi komentarzami. Co więcej, zdaniem niektórych historyków nauki to właśnie wizja świata zawarta w traktatach polskiego alchemika (a nie legendarne jabłko) mogła być inspiracją dla sformułowania przez angielskiego geniusza prawa powszechnego ciążenia ${ }^{13}$.

Chociaż studiował przynajmniej na ośmiu uniwersytetach (przy czym tylko na trzech był formalnie immatrykulowany), Sędziwój nie miał stopnia akademickiego i nic nie wiadomo, aby podjął studia medyczne $^{14}$. Najpewniej już wówczas interesował się głównie alchemią (która nie była oficjalnie wykładana na uniwersytetach) i poszukiwał nieformalnych kontaktów z zajmującymi się nią prywatnie profesorami. Niemniej, kiedy w 1596 r. osiadł już na stałe w Pradze wraz z przywiezioną z Frankonii żoną szlachcianką, zajmował się przynajmniej sporadycznie leczeniem za pomocą alchemicznego panaceum ${ }^{15}$. Niezwykle cennych i szczegółowych informacji na ten temat dostarczają

${ }^{12}$ Bibliografię pism Sędziwoja zawiera praca R. Bugaja, Michał Sędziwój..., dz. cyt., s. 280-303; poprawioną wersję wraz ze szczegółową historią wszystkich edycji przygotowuje piszący te słowa.

${ }^{13}$ K. Figala, Newton as alchemist, „History of Science” 1977, s. 102-137; R.S. Westfall, Newton and alchemy, [w:] Occult and scientific mentalities in the Renaissance, B. Vickers (red.), Cambridge 1984, s. 315-336; W.R. Newman, Geochemical concepts in Isaac Newton's early alchemy, [w:] The revolution in geology from the Renaissance to the Enlightenment, G.D. Rosenberg (red.), Boulder, CO 2009, s. 41-50.

${ }^{14}$ Pochodzący z początku XIX w. spis stopni uzyskanych na uniwersytecie medycznym w Montpellier przez studentów bez immatrykulacji wymienia co prawda „Michael Sendivogius, polonus", ale pod rokiem 1520, co oczywiście jest ewidentną pomyłką. Można się jedynie domyślać, że kompilator tego wykazu, zrobionego na podstawie niezachowanych dzisiaj źródeł, trafił na jakiegoś Sędziwoja z Polski i utożsamił go ze słynnym alchemikiem. Druga możliwość, że błędny jest tylko rok, a Sędziwój istotnie uzyskał stopień doktora medycyny w Montpellier, wydaje się mało prawdopodobna w obliczu faktu, że nigdy takiego tytułu nie używał ani nie wspominali o tym jego współcześni i wcześni biografowie: M. Gouron, (wyd.), Matricule de l'Université de médecine de Montpellier (1503-1599), „Travaux d'Humanisme et Renaissance” 1957, s. 216.

15 R.T. Prinke, Veronika Stiebarin, the wife of Michael Sendivogius, [w:] Sršatý Prajz. Erich Šefčík (1945-2004). Sborník $k$ nedožitým 65. narozeninám historika a archiváře, J. Hanzal, O. Šefčík (red.), Praha 2010, s. 151-162. 
akta procesu, jaki wytoczyła Sędziwojowi rodzina zamożnego mieszczanina praskiego, kupca Ludvíka Korálka.

Korálek był osobą wykształconą, właścicielem jednego $\mathrm{z}$ większych prywatnych księgozbiorów w Pradze i patronem grupy alchemików i poetów, do której dołączył Sędziwój. Kiedy w 1599 r. rozchorował się (z objawów opisywanych w zeznaniach świadków wynika, że przyczyną choroby był alkoholizm), leczyło go kilku znanych lekarzy, członków owej grupy alchemików. Najznaczniejszym z nich był w tym czasie Václav Lavín (Wenceslaus Lavinius) z Ottenfeldu (1550-1602), student i przyjaciel Theodora Zwingera, osobisty lekarz Karla z Žerotína Starszego, autor alchemicznego Tractatus de coelo terrestri, który wszakże sam się wkrótce rozchorował i nie mógł zeznawać podczas procesu $^{16}$. Zeznawał natomiast Oswald Croll (ok. 1560-1609), słynny później lekarz-paracelsysta, autor wpływowego dzieła Basilica chymica (1608), który krótko przed śmiercią Korálka wyjechał do Brna, zapewne spodziewając się oskarżeń ze strony rodziny swego pacjenta ${ }^{17}$. Niewiele też pomógł Korálkowi Mikuláš Lev z Levenštejna, naczelny lekarz Starego Miasta, który wcześniej wprowadził Sędziwoja do praskiego kręgu przyjaciół alchemii. Ten ostatni pozostał przy Korálku i leczył go aż do śmierci 12 czerwca 1599 r., a ponieważ wcześniej pożyczył od swego patrona sporą sumę pieniędzy, siostry i szwagier Korálka oskarżyli Polaka o świadome pozbawienie go życia, żeby nie musieć oddawać długu ${ }^{18}$.

W procesie zeznawało ponad 20 świadków, w tym Croll i Lev, a także Jan Kapr z Kaprštejna (wcześniej związany z przebywającymi w Polsce i Czechach angielskimi alchemikami Johnem Dee i Edwardem Kelleyem) i Georg Humler (Hunkler), zatrudniony w laboratorium Rudolfa II $^{19}$. Świadczyła też cała służba z domu Korálka oraz

${ }^{16}$ J. Michalík, Wenceslaus Lavinius of Ottenfeld (1550-May 1602) and his Earthly Heaven, [w:] Latin alchemical literature of Czech provenance. Proceedings from The Centre for Renaissance Texts Conference [16-17 October 2014], T. Nejeschleba, J. Michalík (red.), Olomouc 2015, s. 148-186.

17 O. Crollius, Alchemomedizinische Briefe 1585 bis 1597 (Ausgewählte Werke 2), W. Kühlmann, J. Telle (wyd.), Heidelberger Studien zur Naturkunde der frühen Neuzeit 6, Stuttgart 1998; J. Hausenblasová, Oswald Croll and his relation to the Bohemian lands, „Acta Comeniana” 2002, s. 169-182.

${ }^{18}$ Základy starého místopisu pražského (1437-1620). Oddil I: Staré město pražské. Dil I., J. Teige (wyd.), Praha 1910, s. 809-816. Por. R. Bugaj, Michat Sędziwój..., dz. cyt., s. 83-96.

19 The private diary of Dr. John Dee and the catalogue of his library of manuscripts, from original manuscripts in the Ashmolean Museum at Oxford, and Trinity College Library, Cambridge, J.O. Halliwell (wyd.), London 1842; J. Rampling, John Dee and the alchemists: Practising and promoting English alchemy in the Holy Roman Empire, „Studies in History and Philosophy of Science” 2012, s. 498-508; M. Wilding, A biogra- 
kilku znajomych mieszczan, jak również Markus Meyzl (Mordecai Meisel) (1528-1601), najbogatszy człowiek w Pradze, zwany „,bankierem cesarza”, od którego Korálek pożyczył pieniądze dla Sędziwoja ${ }^{20}$. $\mathrm{W}$ przeciwieństwie do członków rodziny i służących zmarłego kupca, lekarze i alchemicy - przyjaciele Polaka - zgodnie zeznawali, że Korálek zawsze wychwalał Sędziwoja i twierdził, że pomagało mu tylko lekarstwo od „,polskiego doktora”. Był przekonany, że Sędziwój uratował życie jego córki Zuzany, kiedy inni doktorzy opuścili ją, a także wierzył w jego obietnicę, że przedłuży mu życie do 200 lat. Lev z Levenštejna zeznał, że kiedy się po raz pierwszy spotkali, Sędziwój wyleczył jego syna Jana, który już umierał, nie rozpoznawał rodziców, ale ozdrowiał w kilka godzin po zażyciu szczypty proszku Sędziwoja. Efektywność owego lekarstwa potwierdził Croll, stwierdzając, że był świadkiem jego „cudownego” działania. Sam leczył Korálka, podając mu extractionem et solutionem perlarum et corallorum, czyli typowe dla szkoły Paracelsusa leki mineralne, dobrane na zasadzie prawa sygnatur (naturalnych znaków, w tym przypadku nazwiska pacjenta), o którym w 1609 r. wydał osobny traktat. Natomiast, jak zeznał, Sędziwój aplikował mu summam et universalem medicinam, a więc jakiś specyfik wywiedziony $\mathrm{z}$ wcześniejszej tradycji alchemicznej, w której Kamień Filozofów uważany był również za panaceum na wszelkie choroby ciała. Alchemiczna natura lekarstwa Sędziwoja wynika również wprost z relacji Lva, według której Polak miał dwa proszki - biały i czerwony. Wyleczył nimi jego syna, ale także dał mu odrobinę białego proszku, za pomocą którego Lev później samodzielnie przeprowadził transmutację rtęci w bardzo dobrej jakości srebro. O dokonywanych przez Sędziwoja transmutacjach informował też Kapr, któremu Korálek opowiadał, jak w jego obecności Polak wyjął ze ściany gwóźdź, śrubę i hak do wieszania ubrań, wszystkie z litego żelaza, posmarował je jakimś płynem, położył na pewien czas na rozpalonych węglach na stole - i wszystkie zamieniły się w dobrej jakości srebro, co później Kapr sprawdzał osobiście.

\footnotetext{
phy of Edward Kelly, the English alchemist and associate of Dr. John Dee, [w:] Mystical metal of gold. Essays on alchemy and Renaissance culture, S.J. Linden (red.), New York 2007, s. 35-89; V. Karpenko, I. Purš, Edward Kelly: A star of the Rudolfine era, [w:] Alchemy and Rudolf II. Exploring the secrets of nature in Central Europe in the 16th and 17th centuries, V. Karpenko, I. Purš (red.), Praha 2016, s. 489-534.

${ }^{20}$ G. Veltri, „Ohne Recht und Gerechtigkeit“: Rudolf II. und sein Bankier Markus Meyzl, [w:] An der Schwelle zur Moderne: Juden in der Renaissance, G. Veltri, A. Winkelmann (red.), Leiden 2003, s. 233-255.
} 
Wrażenie, jakie „cudowna moc” lekarstwa Sędziwoja wywarła na wszystkich jego znajomych praskich lekarzach, nie było chwilowym zauroczeniem. Dziesięć lat później Croll dał temu wyraz w swojej $B a$ silica chymica, gdzie opisał zdarzenie, którego był świadkiem (za co dziękuje Bogu), a mianowicie natychmiastowe (w ciagu jednej nocy) i całkowite wyleczenie umierającego człowieka przez podanie jednej tylko kropli tajemniczego płynu przez znakomitego i wielce uczonego męża, nazwanego przez Crolla „Heliocantharus Borealis” (Północny Skarabeusz $)^{21}$. Nie ma wszakże wątpliwości, że chodziło o Sędziwoja, bo w odnośnym fragmencie tekstu zakodowane zostało jego imię - Michael Sendivoius (bez „g”) - za pomocą wielkich liter (tutaj pogrubionych dla łatwiejszego odczytania) ${ }^{22}$ :

Attamen cum opera Dei sint annuncianda, \& celebranda, \& ut hoc monumento relicto constet olim, nostri quoque saeculi hominibus felicitatem suam posteris non invidentibus Beneficentiam illam Divinam non fuisse negatam, in Veritatis attestationem \& subsidium, non possum hoc loco non meminisse singularis illius Divinae erga me Clementiae, quod mini non sine manifesto superum favore ceu oculato testi, in peregrinationibus meis isthaec fortuna, compluribus expetentibus denegata, contigerit, ut illam intueri \& gustare licuerit, apud Magnum aliquem, cui in aeternum bene sIt, \& Cumprimis egregium HeliocAntharum borEaLem, nunc in Christo quiescentem: CujuSmodi lENtis DenIque consueVerunt latitare tempOrum currIcUliS. Unde diu maximo Naturae per artem miraculo cum stupore attonitus, inter varias \& multiplices Inferions Astronomiae metamorphoses (via Antiquorum Humida nondum tamen intense ad Basilisci oculum Exaltata) in frigido factas, mihi hoc unum prodigium, omnium mirabilium superans admirationem, cumprimis stupendum \& spectatu dignissimum fuit, quod unica illius Laticis exhibita gutta (in qua tanquam penuario omnium corporum Coelestium \& Terrestrium dispersae virtutes admirando artificio invisibiliter coacervatae, imo in qua totus mundus Astralice concentratus erat) hominem deploratae valetudinis \& morti vicinum sua Ignea, Astrali \& Coelesti Natura Invisibili influendo Cordi radium Vitae Naturalis, Vitaeque organa renovando, \& defunctam Naturam

${ }^{21}$ R.T. Prinke, 'Heliocantharus Borealis': Alchemy, Polish Sarmatism and the Fourth Northern Monarchy in the prophetic vision of Michael Sendivogius, [w:] Apocalypticism, millenarianism, and prophecy: Eschatological expectations between EastCentral and Western Europe, 1560-1670, H. Hotson, V. Urbánek (red.), Universal Reform: Studies in Intellectual History 1550-1700, vol. 1, Aldershot [w druku].

${ }_{22}$ Tenże, Milczenie alchemików. Tożsamość Michała Sędziwoja zakodowana w tekście Basilica chymica Oswalda Crolla, „Pamietnik Biblioteki Kórnickiej” 2007, s. 217-241. 
(per accidentium aegritudinem causantium remotionem) reparando, una nocte ad firmam \& perfectam revocarit incolumitatem ${ }^{23}$.

Fragment ten nie jest łatwy do przetłumaczenia ze względu na liczne i niejasne aluzje, złożoną składnię oraz nawiązania do teorii alchemiczno-medycznej, ale podstawowy przekaz można przełożyć jak niżej:

Jednak ponieważ dzieła Boga należy rozgłaszać i wielbić, i dlatego żeby z niniejszego ich pomnika wiadomo później było, że owa Łaska Boga nie została odmówiona również ludziom naszego wieku, którzy nie zazdrościli potomnym ich szczęśliwości, nie mogę w tym miejscu nie wspomnieć, w imię dania świadectwa i potwierdzenia Prawdy, o owej szczególnej wobec mnie Boskiej łaskawości, jako że zdarzyło mi się podczas mych podróży, nie bez wyraźnej przychylności Nieba, jako naocznemu świadkowi, to szczęście - które wielu innym, szczerze go pragnącym, nie było dane - iżbym ją ujrzał i jej posmakował u pewnego Wielkiego, któremu niech się wiecznie dobrze dzieje, a nade wszystko wielce uczonego męża [którego nazywam] Heliocantharus Borealis, dziś już spoczywającego w Chrystusie. Tego rodzaju zdarzenia, bowiem, zwykle zostają ukryte $\mathrm{w}$ wolnych przebiegach czasu [=zapomniane]. Odtąd będąc przez długi czas zadziwiony tym największym cudem Natury dokonanym przez Sztukę, pośród różnych i wielorakich zjawisk metamorfozy Niższej Astronomii dokonywanych na zimno (Wilgotna droga Starożytnych nie została jeszcze wyraźnie wyniesiona do oka Bazyliszka), ten jeden cud, znacznie bardziej godny podziwu niż wszelkie inne cuda, wydawał się niezwykły i w najwyższym stopniu wart zobaczenia, jak przez podanie jednej tylko kropli owego Płynu (w którym, niczym w magazynie, rozproszone cnoty wszystkich ciał Niebieskich i Ziemskich zostały cudowną sztuką zebrane, a nawet więcej, w którym cały świat został skoncentrowany), ciężko chory, umierający człowiek wyzdrowiał dzięki jego Ognistej, Astralnej i Niebiańskiej Niewidzialnej Naturze, przekazując do Serca promień Naturalnego Życia, odnawiając organa Życia, i naprawiając Naturę, która (w wyniku utraty przez przypadkową chorobę) została nadwyrężona i zmarnowana, przywracając go do dobrego i doskonałego zdrowia w ciągu jednej nocy ${ }^{24}$.

Takie świadectwo jednego $\mathrm{z}$ najważniejszych uczonych lekarzy epoki, paracelsysty, ale z uniwersyteckim wykształceniem medycznym i doskonałą znajomością również medycyny galenowskiej, nie

${ }^{23}$ O. Crollius, Basilica chymica, Francofurti 1608, s. 94-95.

${ }^{24}$ Dziękuję Annie Pawlaczyk za konsultację tłumaczenia i pomoc w rozwikłaniu subtelności tekstu. 
świadczy oczywiście o rzeczywistej „cudowności” specyfiku stosowanego przez Sędziwoja (tak jak relacje o dokonywanych przez niego transmutacjach metali nie dowodzą istnienia takiej możliwości). Jest to raczej świadectwo stanu ówczesnej medycyny, w której dopuszczana była możliwość istnienia panaceum, a praktyczna weryfikacja efektywności lekarstw pozostawiała wiele do życzenia.

O eliksirze Sędziwoja wspomina też piszący w latach 20. XVII w. (a więc za jego życia) czeski lekarz Matthäus Erbinäus von Brandau w książce poświęconej w całości „universalnemu lekarstwu i złotej tynkturze”, czyli Kamieniu Filozofów. Podaje on zasłyszaną informację o „Panu Obmauskim” (Herr Obmausky), gubernatorze Krakowa, który dzięki „bożemu błogosławieństwu i tynkturze Sędziwoja” w wieku 85 lat do tego stopnia został odmłodzony, że trzeba mu było postawić nowy horoskop urodzeniowy ${ }^{25}$. Trudno tę informację zweryfikować, bo nazwisko owego „gubernatora” jest w oczywisty sposób zniekształcone, a żaden z ówczesnych urzędników krakowskich nie nosił podobnego (poza ewentualnie Mikołajem Herburtem Odnowskim, wojewodą krakowskim, który wszakże zmarł jeszcze przed urodzeniem Sędziwoja) ${ }^{26}$.

Dalszą ewolucję legendy Sędziwoja jako lekarza cudotwórcy dokumentuje również fragment jego najwcześniejszej biografii Vita Sendivogii Poloni, napisanej krótko po jego śmierci przez nieznanego z nazwiska niemieckiego autora:

Był on [Sędziwój] wszakże nie tylko alchemikiem, ale w istocie zdawał się być też magiem. Albowiem widziałem i czytałem listy pisane do niego, z wylewnymi podziękowaniami za użycie magii do wyleczenia osoby ciężko doświadczanej przez zupełnie nieznaną chorobę. Ów chory doznawał co jakiś czas napadów podobnych do epilepsji i podczas tych skurczów wymiotował wielokrotnie starymi monetami różnych rodzajów i wieloma innymi obcymi ciałami, takimi jak część klucza, gwoździe, pręt żelazny czy końskie kopyto itd. Chociaż Sędziwój był oddalony o sto mil, jak się zdaje napisali do niego z prośbą o opinię, co należy uczynić w takiej potrzebie. Ten odpisał, żeby mu przysłali owe

${ }^{25}$ M. Erbinäus von Brandau, Warhaffte Beschreibung von der Universal-Medicin und Güldnen Tinctur, Leipzig 1689, s. 35: „Hr. OBMAUSKY, Gubernator zu Cracau in Pohlen lebet ietzt durch göttl. Seegen und SENDIVOGENS Tinctur in das 85. Jahr / hat ihm neulich das Nativität stellen lassen / wil vielleicht auffs neue anfangen zuleben"; na temat książki i jej autora zob.: V. Karpenko, Matthäus Erbinäus von Brandau: alchymie mezi realitou a fantazí, [w:] Alchymie a Rudolf II..., dz. cyt., s. 393-422.

${ }^{26}$ S. Cynarski, A. Falniowska-Gradowska, Urzędnicy województwa krakowskiego XVI-XVIII wieku. Spisy, Kórnik 1990. 
rzeczy, które chory zwymiotował, a krótko po uczynieniu tego, pacjent wyzdrowiał ${ }^{27}$.

Nie trzeba, rzecz jasna, dowodzić, że oba te przekazy nie są wiarygodne w zakresie efektów opisanych działań medycznych. Stanowią wszakże istotny przyczynek do poznania panujących wówczas opinii o możliwościach medycyny alchemicznej i magicznej, jak również postrzegania Sędziwoja jako ich wielkiego adepta. Trudno natomiast na tak skąpej podstawie wysnuć jakiekolwiek hipotezy co do ewentualnego źródła owych relacji w rzeczywistych poczynaniach Sędziwoja.

Jeszcze mniej wiarygodna, choć bardziej prawdopodobna, jest krótka wzmianka w późniejszej biografii Sędziwoja, spisanej w 1651 r. przez Pierre'a Des Noyersa (Desnoyers, 1606-1693), uczonego sekretarza królowej Marii Ludwiki, a opublikowanej razem z cytowaną powyżej ${ }^{28}$. Tu po raz pierwszy pojawia się „czarna legenda” Sędziwoja, zgodnie z którą był on zwykłym oszustem, a wydane przez niego traktaty nie były jego autorstwa, ale pewnego Anglika (później utożsamianego ze Szkotem Aleksandrem Setonem, ale najpewniej stanowiącego reminiscencję Edwarda Kelleya) ${ }^{29}$. Otrzymaną od niego tynkturą miał też, według Des Noyersa, leczyć ludzi w Krakowie, w tym króla Zygmunta III Wazę:

W końcu, widząc że zostało mu ledwo trochę owego proszku, sporządził nieco ducha wina [alkoholu], który rektyfikował i rozpuścił w nim resztę proszku. W ten sposób został doktorem i zawstydził wszystkich innych cudownymi wyleczeniami, jakich dokonywał. A czynił to tym

${ }_{27}$ P. Borel, Trésor de Recherches et Antiquitez gauloises et françoises. Redvites en ordre alphabetique. Et enrichies de beaucoup d'Origines, Epitaphes, \& autres choses rares \& curieuses, comme aussi de beaucoup de mots de la Langue Thyoise ou Theuthfranque, Paris 1655, s. 477: „At non tantum Alchymista fuit, verùm \& Magus fuisse videtur, cùm viderim \& legerim literas, quæ ad ipsum scriptæ fuerant, gratiarum actione repletissimæ, super casu, quo magicè curauerat hominem, qui morbo planè incognito vexatus, per interualla paroxismis quasi epilepticis percutiebatur, \& in istis angustiis constitutus euomebat, diuersis vicibus omnis generis monetas veteres, aliasque res planè alienas, vt mox frustum alicuius clauis, mox claui, fustis ferrei, vngulæ equi, \& cætera. Hic cùm vel centum milliaribus à Sendiuogio abesset, visum est, vt scripto requiretur consilium eius super præsenti necessitate. Respondit, vt res, quas euomuisset ægrotus ad se mitterentur, quo facto, pauco post tempore ager conualuit”.

${ }_{28} \mathrm{Na}$ temat Des Noyersa zob.: K. Targosz, Uczony dwór Ludwiki Marii Gonzagi (1646-1667). Z dziejów polsko-francuskich stosunków naukowych, Wrocław 1975; F. Secret, Astrologie et alchimie au XVIIe siècle: Un ami oublié d'Ismael Boulliau Pierre des Noyers, secrétaire de Marie-Louise de Gonzague, reine de Pologne, „Studi Francesi" 1976, s. 463-479.

${ }^{29}$ R. Prinke, Beyond patronage..., dz. cyt., s. 186-189. 
samym płynem, którym zabarwił na czerwono [=przemienił w złoto] posiadany przeze mnie medal [...], a transmutacji tej dokonał przed obliczem Zygmunta III, którego, co więcej, ten sam Sędziwój wyleczył $\mathrm{z}$ bardzo ciężkiej choroby tym samym eliksirem ${ }^{30}$.

Większość podawanych przez Des Noyersa faktów z życia polskiego alchemika okazała się nieprawdziwa w zestawieniu z autentycznymi źródłami ${ }^{31}$, a więc zapewne i ten epizod w rzeczywistości nie miał miejsca, tym bardziej że nie potwierdza go żadne inne źródło. Najpewniej opowieść taką usłyszał Des Noyers od osoby, która mu sprzedała wspomniany medal i chciała uwiarygodnić jego autentyczność.

Polski alchemik nie polegał jednak wyłącznie na owym panaceum w swojej praktyce lekarskiej, ale uwzględniał również tradycyjną medycynę galenowską, o czym świadczy jego egzemplarz Pharmacopoeia Augustana w wydaniu z 1613 r., który ofiarował w roku 1623 młodemu Janowi Brożkowi, wówczas studentowi w Padwie (gdzie zapewne się spotkali). Późniejszy rektor Uniwersytetu Krakowskiego i biograf Kopernika odnotował to na karcie tytułowej: „Joannes Broscii Curzelouiensis Doctoris Medicinae anno 1623 dono D. Michaelis Sandivogii”. U dołu strony dopisał jeszcze: „duerniones D et E perturbati sed sunt integri ut notavit ibidem D. Sendivogius”. Rzeczywiście składki D i E zostały przestawione podczas oprawiania tomu i po stronie 12. następuje 17., a na tej poprzedniej widnieje symbol Wenus (albo alchemiczny znak miedzi) z krótką adnotacją: „† vide inferius post folia duo”. Ten sam znak Wenus widnieje na początku strony 13., która następuje po $20 .{ }^{32}$ Można zatem przyjąć, że Sędziwój w ten sposób oznaczał odsyłacze w swoich książkach choć Pharmacopoeia jest jedyną znaną pozycją pochodzącą z jego biblioteki. Ponieważ takie zastosowanie symbolu Wenus jest raczej unikatowe, odkrycie go w innych książkach z epoki może wskazywać na ich proweniencję z księgozbioru polskiego alchemika. Omawiany tom jest obficie adnotowany przez Brożka (m.in. podaje polskie od-

${ }^{30}$ P. Borel, Trésor de Recherches et Antiquitez..., dz. cyt., s. 483: „Enfin, voyant qu'il n'auoit plus guere de cette poudre, il s'auisa de tirer de l'esprit de vin, qu'il rectifia, $\&$ mit le reste de sa poudre dedans, \& fit le Medecin, faisant honte à tous les autres par les cure merueilleuses qu'il faisoit. Et c'est dans cette mesme liqueur qu'ayant fait rougir la medaille que i'ay il la transmua [...]; \& cela il le fit deuant Sigismond III. lequel encore ledit Sendiuogius guerit d'vn tres-facheux accident auec le mesme Elixir."

31 R.T. Prinke, The twelfth adept. Michael Sendivogius in Rudolphine Prague, [w:] The Rosicrucian Enlightenment revisited, R. White (red.), Hudson, NY 1999, s. 141-192.

${ }^{32}$ Fotografie odnośnych stron przekazał mi uprzejmie Michał Choptiany, za co niniejszym dziękuję. 
powiedniki łacińskich nazw roślin w recepturach), ale nie zawiera żadnych innych wpisów Sędziwoja ${ }^{33}$.

Co ciekawe, w znanych źródłach dotyczących Sędziwoja nie ma żadnych śladów jego zainteresowania doktryną medyczną Paracelsusa i jego następców. Przywołane wcześniej zeznania Crolla i jego świadectwo w Basilica chymica pokazują dobitnie, że nie traktował ,polskiego lekarza" jako przedstawiciela tej samej szkoły medycznej. Również inni współcześni autorzy nie dostrzegali w Sędziwoju paracelsysty, jak choćby Andreas Libavius, zajadły krytyk wszystkich wyznawców nauk szwajcarskiego lekarza, który opublikował bardzo pochlebną obszerną recenzję De lapide philosophorum ${ }^{34}$, albo Michael Maier, który przedstawił Sędziwoja jako ostatniego w łańcuchu 12 największych adeptów wszystkich czasów ${ }^{35}$. W swoich drukowanych tekstach alchemik nigdzie nie wspomina o Paracelsusie, a niektóre pojęcia zaczerpnięte $\mathrm{z}$ jego spuścizny pojawiają się $\mathrm{w}$ innym znaczeniu (archeus) lub stały się już wcześniej elementem tradycyjnej alchemii za pośrednictwem pism pseudoepigraficznych przypisywanych Paracelsusowi (tria pri$m a)^{36}$. Niemniej, wielu badaczy nadal określa Sędziwoja mianem paracelsysty $^{37}$, a Roman Bugaj postawił nawet hipotezę, że w swej praktyce medycznej był wyznawcą tej właśnie szkoły, na co jedynym argumentem miały być jego wizyty w Marburgu i Padwie ${ }^{38}$. O naturze tej drugiej podróży nie wiadomo nic poza wspomnianą dedykacją dla Brożka w podarowanym mu dziele z zakresu tradycyjnej medycyny galenowskiej, a ponadto nauki Paracelsusa znalazły niewielki oddźwięk we Włoszech i były całkowicie pomijane na tamtejszych uniwersytetach ${ }^{39}$.

${ }^{33}$ Roman Bugaj sugerował, że adnotacje pochodzą od Sędziwoja (R. Bugaj, Michał Sędziwój..., dz. cyt., s. 144), ale Michał Choptiany, badacz rękopiśmiennej spuścizny Brożka, zdecydowanie zidentyfikował jego rękę (informacja prywatna).

34 A. Libavius, Septadis Hermeticae monas septima, continens inuestigationem veri artificii in Nouo lumine Michaelis Sendivogii, [w:] Syntagmatis arcanorum chymicorum [...] tomus secundus, Frankfurt 1613, s. 437-453.

${ }_{35}$ M. Maier, Symbola aureae mensae duodecim nationum, Frankfurt a. M. 1617, s. 553-621.

${ }^{36}$ Zmarły niedawno Joachim Telle, jeden z najlepszych współczesnych autorytetów w zakresie alchemii i późnego paracelsysmu, również nie zalicza Sędziwoja do tego nurtu, uznając, że jego pisma zdradzają „co najwyżej złamane [gebrochene] uczestnictwo w specyficznym skarbcu doktryny Paracelsusa”. Corpus Paracelsisticum. Bd. III: Dokumente frühneuzeitlicher Naturphilosophie in Deutschland. Der Frühparacelsismus. Dritter Teil, W. Kühlmann, J. Telle (wyd.), Berlin-Boston 2013, s. 954.

37 H. Trevor-Roper, The Paracelsian movement, [w:] tegoż, Renaissance essays, Chicago-London 1985, s. 181.

${ }^{38}$ R. Bugaj, Michat Sędziwój..., dz. cyt., s. 157.

${ }^{9}$ P.F. Grendler, The University of Mantua, the Gonzaga, and the Jesuits, 1584-1630, Baltimore 2009, s. 134-135. 
Jedynym źródłem wiadomości o domniemanej wizycie Sędziwoja w Marburgu jest list napisany w $1661 \mathrm{r}$. po włosku (ale znany jedynie z tłumaczenia francuskiego) przez Hieronima Pinocciego, kupca i dyplomatę z Krakowa ${ }^{40}$. Skierowany do nieznanego adresata, zawiera on krótkie informacje biograficzne o Sędziwoju, częściowo zebrane przez Pinocciego od pamiętających alchemika osób. Dowodząc tezy jakoby Polak nie był autorem opublikowanych przezeń traktatów, przywołuje relację Szymona Piotra Batkowskiego, według której w 1616 r. Sędziwój odwiedził Johanna Hartmanna, profesora chymiatrii na uniwersytecie w Marburgu, przyciągnięty jego sławą. Miał tam publicznie, w obecności studentów, pokazać swoją tynkturę i wykonać z nią próby, a także stwierdzić otwarcie, że zarówno ona, jak i opublikowany traktat o Kamieniu Filozofów były dziełem jego przyjaciela Anglika ${ }^{41}$. Roman Bugaj uznał tę relację za wiarygodną i na tej wątłej podstawie skonstruował hipotezę o wizycie Sędziwoja jako gościa honorowego na dworze landgrafa Maurycego Uczonego, który miał dokonać tam transmutacji w obecności Michaela Maiera, na co nie ma żadnych dowodów ${ }^{42}$. Co więcej, w wydanych później komentarzach do Basilica chymica Hartmann określił Sędziwoja mianem „eine Polacke” (pewien Polak) ${ }^{43}$, co z pewnością nie wskazuje na dobra znajomość czy wręcz przyjaźń, jak sugerował Bugaj. Wątpliwości co do owej wizyty podnosił przekonująco już w 1966 r. Włodzimierz Hubicki, który wcześniej przeprowadził kwerendę w archiwach w Marburgu i Kassel i nie znalazł żadnej wzmianki o odwiedzinach Sędziwoja ${ }^{44}$. Rów-

${ }^{40}$ P. Micigno, Lettre missive, contenant la vie de Sendivogius, [w:] Cosmopolite ou Nouuelle lumiere chemique, divisée en douze traitez, Paris 1669, vol. 2, bez paginacji; na temat Pinocciego zob.: K. Targosz, Hieronim Pinocci. Studium z dziejów kultury naukowej w Polsce w XVII wieku, Wrocław 1967.

${ }^{41}$ Micigno, Lettre missive: „Ie croy que vous vous contenterez que pour preuve de cecy, ie vous die seulement que luy-mesme l'a confeßé de sa propre bouche l'année 1616 en Marpurg. La renommée de Iean Harthman premier Professeur de cette Academie l'avoit attiré en cette ville, comme außi le desir qu'il avoit de conferer avec luy sur ses labeurs Chymiques. Un iour en presence de plusieurs de ses escoliers (parmy ceux-cy estoit Simon Pierre Batcoschi Noble Prutain, qui est l'un des trois que ie vous ay dit-cy-dessus estre encore en vie, lesquels ont eu une particuliere connoissance et pratique avec Sendivogius) luy fit voir sa teinture liguide et l'épreuve d'icelle, luy ayant apres confeßé ignenûment que cette Medecine là, außi-bien que le livre de la Pierre des Philosophes, qu'il avoit donné au public, estoit un œuvre de l'Anglois son amy”.

${ }^{42}$ R. Bugaj, Michał Sędziwój..., dz. cyt., s. 140-142; podany przez Bugaja cytat z Maiera został błędnie zinterpretowany, a dotyczy relacji Crolla w Basilica chymica.

${ }^{43}$ O. Crollius, Chymisch Kleynod, Frankfurt 1647, s. 119, przypis k.

${ }^{44}$ K. Targosz, Kronika II (referat prof. Hubickiego), „,Kwartalnik Historii Nauki i Techniki” 1966, nr 2, s. 475-476; W. Hubicki, Uczniowie z Polski na studiach chymiatrii w Marburgu w latach 1609-1620, „Studia i Materiały z Dziejów Nauki Polskiej” 1968, s. 96-99. 
nież późniejsi badacze zajmujący się laboratorium Hartmanna i alchemicznym kręgiem landgrafa Maurycego nie natrafili na jakąkolwiek informację w tym względzie, analizując szczegółowo obszerną korespondencję wielu alchemików związanych $\mathrm{w}$ tym czasie $\mathrm{z}$ dworem Maurycego, a także samego Hartmanna i jego uczniów ${ }^{45}$. Szymon Piotr Batkowski z Łobżenicy (zm. ok. 1669 r.) istotnie studiował medycynę w Marburgu i był w gronie prywatnych studentów Hartmanna w latach 1615-1616, a następnie udał się do Heidelbergu, gdzie w 1617 r. uzyskał stopień doktora ${ }^{46}$. Nie zrobił jednak kariery i ok. 1660 r. trafił pod skrzydła Pinocciego, który pomógł mu w otrzymaniu pracy w kancelarii królewskiej, ale wkrótce zraził się do niego, był bowiem „pogardliwy i niepohamowany w jedzeniu”. Później Pinocci mimo wszystko sam go zatrudnit, ale w 1663 r. z jakiegoś powodu Batkowski został skazany na infamię i usiłował się oczyścić przed Trybunałem Lubelskim ${ }^{47}$. W świetle tych ustaleń wydaje się oczywiste, że Batkowski wymyślił cały epizod wizyty Sędziwoja w Marburgu, aby się uwiarygodnić i zdobyć zaufanie Pinocciego, potwierdzając fałszywą (jak dzisiaj wiadomo) tezę, przejętą od znanego mu osobiście Des Noyersa, jakoby polski alchemik nie był autorem opublikowanych przezeń traktatów. Tym samym nie ma żadnej przesłanki, aby uznać Michała Sędziwoja za zwolennika paracelsyzmu, natomiast wiele wskazuje na to, że łączył tradycję alchemiczną z klasyczną medycyną galenowska.

Najdobitniej świadczy o tym wypowiedź samego Sędziwoja w traktacie De sulphure (1616), gdzie mówiąc o dawnych mędrcach, rozumiejących Naturę i pozostających z nią w przyjaźni, wymienia z imie-

${ }^{45}$ Informacje prywatne od Bruce'a Morana i Fritza Kraffta; por. również ich liczne publikacje na ten temat, szczególnie: B.T. Moran, Der alchemistisch-paracelsische Kreis um den Landgrafen Moritz von Hassen-Kassel (1572-1632). Der fürstliche Forscher und die Methode experimenteller Wissenschaft, [w:] Paracelsus und Paracelsisten. Vorträge 1984/85, Wien 1987, s. 119-145; tenże, The alchemical world of the German court. Occult philosophy and chemical medicine in the circle of Moritz of Hessen (1572-1632), Stuttgart 1991; tenże, Chemical pharmacy enters the university. Johannes Hartmann and the didactic care of chymiatria in the early seventeenth century, Madison, WI 1991; F. Krafft, The magic word chymiatria - and the attractiveness of medical education at Marburg, 1608-1620. A somewhat different reflection on attendance, [w:] History of Universities: Volume XXVI/1, M. Feingold (red.), Oxford 2012, s. 1-116; tenże, Im Fokus angehender Mediziner des protestantischen Europa: Marburg 1608 bis 1620, [w:] Heilkunde und Heilmittel: Zum Erwerb und Transfer von medizinisch-pharmazeutischem Wissen in Europa, J. Kiefer (red.), Aachen 2013, s. 263-282.

${ }^{46}$ W. Hubicki, Uczniowie..., dz. cyt., s. 204-205; F. Krafft, The magic word chymiatria..., dz. cyt., s. 28, 41, 70.

${ }^{47}$ K. Targosz, Hieronim Pinocci..., dz. cyt., s. 111-112; W. Hubicki, Z dziejów chemii i alchemii..., dz. cyt., s. 205. 
nia Hermesa, Arystotelesa i Awicennę. Oni też, a także wspomniany dalej Galen, potrafili rozpoznawać cechy wszelkich rzeczy za pomocą zwierciadła Natury i dzięki temu byli najlepszymi lekarzami. Albowiem ,gdy lekarz wie tylko z książek Galena albo Awicenny, nie zaś ze źródła Natury, skąd właśnie uzyskiwali to owi słynni medycy, dlaczego to zioło jest takie, a tamto inne, dlaczego w takim stopniu ciepła lub suchości albo wilgoci, nigdy nie może być on rzetelnym lekarzem"48. Nie jest to w żadnej mierze krytyka twórców klasycznej medycyny, ale pochwała ich metody, bo „zostawili swe pisma swoim następcom, aby zachęcić ludzi do głębszych studiów”, podczas gdy „ludzie tego wieku, uważając ich pisma za ostateczną podstawę, nie szukają już niczego więcej, wystarcza im, że powiedzą: tak pisał Arystoteles, a tak Galen" ${ }^{49}$. Sędziwój uznaje zatem wielką wartość medycyny Galena i Awicenny, namawiając jednocześnie do jej rozwijania w oparciu o obserwację przyrody, a nie ograniczania się do bezrefleksyjnej akceptacji ich autorytetu. Dalej wyjaśnia, że „owi dawni filozofowie odpisywali swe recepty ze źródła samej Natury" i każdy może nadal tak robić, musi tylko zrozumieć jak wszystko powstaje „,z trzech pierwiastków: ongiś dwóch [rtęci i siarki], do których jednak jest dołączony trzeci [sól]" "50. Ponieważ dodanie tego trzeciego pierwiastka i stworzenie koncepcji tria prima było zasadniczo dziełem Paracelsusa, brak odwołania się do niego w tym kontekście (a także gdziekolwiek indziej) trzeba odczytać wręcz jako manifestacyjne odrzucenie paracelsyzmu i opowiedzenie się za klasyczną medycyną Galena i Awicenny w połączeniu z empiryczną tradycją alchemii.

Przytoczony tu fragment stanowi jedną z bardzo nielicznych i marginalnych wzmianek dotyczących medycyny i lekarstw w opublikowanych pismach polskiego alchemika, ich główną treść stanowią bowiem kwestie transmutacji metali, budowy materii i działania przyrody. Nawet $w$ tych kilku zaledwie przypadkach nie zawsze jest oczywiste, czy autor miał na myśli leczenie chorób u ludzi, czy może leczenie metali z ich niedoskonałości, jak często przedstawiane jest metaforycznie działanie Kamienia Filozofów. W kolejności chronologicznej: De lapide philosophorum (1604) zawiera tylko jedną taką wzmiankę, i to w dołączonej na końcu zagadce filozoficznej - Parabola seu Aenigma philosophicum - napisanej zgodnie z konwencją tradycyjnej alchemii $\mathrm{w}$ formie przypowieści. We fragmencie tym Saturn wyjaśnia, jak owo-

${ }^{48}$ M. Sędziwój, Traktat o kamieniu filozoficznym, tłum. R. Bugaj, Warszawa 1971, s. 282.

${ }^{49}$ Tamże.

${ }^{50}$ Tamże, s. 283. 
ce Drzewa Słońca należy rozpuścić w wodzie życia, po czym dodaje: „Przed właściwym gotowaniem [...] jest to najsilniejsza trucizna, lecz po powolnym gotowaniu staje się najlepszym lekarstwem i dostarcza 29 granów krwi; ale każdy gran dostarczy ci 864 owoców drzewa słonecznego" 1 .

Najprawdopodobniej nie chodzi tu jednak o krew człowieka, ale symboliczną krew, jaka pojawia się często $\mathrm{w}$ ikonografii alchemicznej i przedstawia jakąs substancję chemiczną, w tym przypadku uzyskiwaną z innej, w drodze powolnego podgrzewania. Nie jest jednak wykluczone, że substancja ta miała też służyć leczeniu ludzi - co do pewnego stopnia potwierdzają późniejsze wzmianki.

Dialogus (1607) zawiera tylko jedno, jeszcze bardziej enigmatyczne odniesienie do leczenia. Kiedy Merkuriusz (Rtęć) wyjaśnia Alchemikowi swoją budowę i nakazuje połączyć powietrze z powietrzem, a następnie z ogniem, instruuje go dalej: „To, co zbędne, usuń, a pozostałe spal na ogniu i umieść $\mathrm{w}$ wodzie, następnie gotuj, a ugotowane dostarczy lekarstwa leczącego choroby".

Alchemik wpada w złość, bo nie może nic zrozumieć z wyjaśnień Merkuriusza i zamierza zmienić swoje dotychczasowe łagodne podejście. Wykrzykuje w reakcji na powyższą wypowiedź:

Nie odpowiadasz na moje pytania. Widzę, że jedynie pragniesz mnie zwieść zagadkami. Żono, przynieś mi łajna świńskiego, pragnę bowiem tego Merkuriusza traktować nowym sposobem, aż mi wreszcie powie, jak należy z niego preparować kamień filozoficzny ${ }^{52}$.

W tym przypadku Sędziwój zapewne miał na myśli lekarstwo działające na ludzi, ale kontekst jest zbyt niejasny, aby podjąc się jego chemicznej identyfikacji - jeśli taka jest tu w ogóle możliwa, bo kategorie pojęciowe alchemii nie przekładają się bezpośrednio na współczesne pojęcia chemiczne. Dotyczy to również trzeciego traktatu - De sulphure (1616) - w którym tytułowa Siarka nie jest w żaden sposób związana z chemiczną siarką, ale stanowi zasadę tworzącą metale (obok Rtęci/Merkuriusza i Soli). Znajdujemy i tam krótki fragment (zaraz po cytowanej już wyżej pochwale Arystotelesa, Galena i Awicenny) o jej leczniczych właściwościach, ujęty znów w formę dialogu Alchemika z Głosem (później zidentyfikowanym jako Saturn) i wyraźnie nawiązujący do Owoców Słońca z De lapide:

${ }^{51}$ Tamże, s. 118-119.

52 Tamże, s. 226. 
Alch[emik]: Panie, mówi się, że siarka jest lekarstwem.

Głos [Saturn]: Owszem, ona sama jest lekarstwem, a tym, którzy ją uwalniają z więzienia, daje ona z wdzięczności nawet swą własną krew jako lekarstwo.

Alch.: Panie, jak długo człowiek, mając takie lekarstwo uniwersalne, może ochronić się przed śmiercią?

Głos: Aż do kresu śmierci [Usque ad terminum mortis], ale lekarstwa tego trzeba zażywać ostrożnie, gdyż wielu mężów umarło przez nie przed czasem.

[...]

Alch.: Panie, ja umiem zrobić to lekarstwo.

Głos: Jesteś więc szczęśliwy, skoro to potrafisz; ponieważ jest to krew Siarki, jej wewnętrzna moc i suchość; one to przemieniają i zestalają żywe srebro w złoto, a także przywracają do zdrowia wszystkie metale i ludzkie ciała ${ }^{53}$.

W miare jasne staje się, że lekarstwem uniwersalnym, panaceum i tynkturą przemieniającą rtęć w złoto jest tutaj „krew Siarki”, czyli jej „moc i suchość”. A ponieważ Siarka jest zasadą determinującą cechy danego metalu - w szczególności jego barwę, przez co nazywana bywa tynkturą, podobnie jak Kamień Filozofów - to „uwolnienie” jej $\mathrm{z}$,więzienia” oznacza najpewniej wyizolowanie Siarki złota i wydobycie z niej „krwi”, która dodana do obojętnej rtęci powoduje jej transmutację w złoto, a jednocześnie stanowi potężne lekarstwo.

W dalszej części rozmowy Saturn staje się sarkastyczny, wykpiwając przechwałki Alchemika, aż w końcu narrator podsumowuje pojawiający się we wszystkich traktatach motyw głupiego alchemika, który nie potrafi zrozumieć działania przyrody. Szczególnie interesująca jest tu zdecydowanie negatywna opinia Sędziwoja o lekarzach, którzy wcześniej zajmowali się alchemią i niczego nie osiągnęli (niewątpliwie chodzi o chymiatrów-paracelsystów):

Kamień [filozoficzny] jednak uciekł i ucieka aż do teraz, dlatego nazywa się go lotnym. I tak ów biedny alchemik nie nauczył się niczego innego z tego przywidzenia, jak tylko robienia świeczek siarkowych. Straciwszy kamień stał się później lekarzem, a szukając kamienia filozoficznego nabawił się kamienia nerkowego. W końcu prowadził życie jak inni tacy sami alchemicy, którzy stają się przeważnie lekarzami lub wytwórcami mydła, co zdarza się wszystkim, którzy zbliżają się do sztuki bez podbudowy, słuchając albo biorąc rzeczy w sposób przypadkowy z receptur ${ }^{54}$.

${ }^{53}$ Tamże, s. 283-284.

${ }^{54}$ Tamże, s. 289-290. 
W stwierdzeniu Sędziwoja jest sporo prawdy, alchemicy bowiem, poszukując Kamienia Filozofów, zdobywali olbrzymie doświadczenie praktyczne w zakresie operowania technologiami chemicznymi, co pozwalało im - po rozczarowaniu brakiem rezultatów przy niezliczonych próbach transmutacji metali - zając się wytwarzaniem jatrochemicznych farmaceutyków albo produkcją rzemieślniczą (na przykład mydła) w obszarze chemii. Na zakończenie polski alchemik sugeruje, że zna recepturę Kamienia Filozofów, ale jest to sztuka zbyt szlachetna i wzniosła, aby ją ujawniać, niczym jakiś banalny przepis kulinarny: „uważamy, że napisaliśmy dostatecznie dużo, aż przyjdzie ktoś inny, kto napisze całą receptę podobnie jak przepis na robienie sera, czego nam nie godzi się"55.

Nie był wszakże konsekwentny, bo już 12 lat wcześniej w „Traktacie Jedenastym” De lapide philosophorum, zatytułowanym „De praxi, et confectione Lapidis seu Tincturae, per artem”, podał częściową i bardzo zawoalowaną recepturę, zaznaczając jednocześnie, że jego wiedza dalej nie sięga. Jednocześnie w obiegu znajdowało się kilka wersji pełnej receptury na „Tynkturę Sędziwoja”, krążących w odpisach rękopiśmiennych, a później także drukowanych. Wspomniany wcześniej Erbinäus von Brandau zapisał taką recepturę zatytułowaną „Sulphur Solis in 1/2 Stunde zu extrahiren”, a więc na ekstrahowanie Siarki Słońca (czyli złota), co zgadza się z cytowanymi wcześniej fragmentami z Sędziwoja o „Krwi Siarki”, a także zasadniczo powiela część procesu z De lapide ${ }^{56}$. Dwie podobne, ale znacznie obszerniejsze procedury wydał w tym samym czasie Johann Joachim Becher (znany jako twórca teorii flogistonu) pod wspólnym nagłówkiem „Processus D. Michaelis Sendivogii super centrum universi, seu Sal centrale" ${ }^{\text {"57 }}$. Wcześniejszą ewolucję przypisywanej Sędziwojowi receptury prześledził Rolf Gelius, który odnalazł osiem jej wersji rękopiśmiennych ${ }^{58}$. Jego zdaniem najwcześniejsza i jednocześnie najkrótsza (dwie strony) redakcja powstała między rokiem 1604 a 1618. Data post quem wynika wszakże z przekonania Geliusa, że pierwotna wersja nie pochodziła

55 Tamże, s. 290-291.

${ }^{56}$ M. Erbinäus von Brandau, XII. Grund-Säulen der Natur und Kunst, worauf die Verwandelung der Metallen gebauet, benebst V. Vornehmer Artisten wahrhafften Processen, Leipzig 1689, s. 21-23.

57 J.J. Becher, Chymischer Glücks-Hafen, oder Große Chymische Conkordanz und Collection von funffzehen hundert Chymischen Processen, Franckfurt 1682, s. 231-240.

58 R. Gelius, Der „Processus universalis“ nach Michael Sendivogius. Zur Entstehungsgeschichte einer neuzeitlichen Variante des alchimischen Grossen Werkes, „Gesnerus" 1996, s. 183-193. 
od Sędziwoja, ale stanowiła interpretację i uzupełnienie wspomnianej receptury z De lapide philosophorum, dokonaną przez jakiegoś innego alchemika. Jego argumentacja nie jest jednak przekonująca, albowiem cztery rękopisy zawierają nazwiska ich autorów: dwa najstarsze (spisane przed 1618 r.) podają, że recepta została zapisana przez Jacoba Alsteina, a dwa inne (datowane przed 1635 r.) wskazują Jana Bodowskiego, służącego Sędziwoja, jako informatora, oraz Johanna Baptistę Grosschedela jako autora tej redakcji recepty. Ponieważ Gelius nie zidentyfikował dobrze tych osób i nie znał istotnych informacji o nich, nie wyciągnął właściwych wniosków. Tymczasem można wykazać źródłowo, że Alstein przebywał w Pradze w 1604 r., skąd wrócił do Paryża z tekstem De lapide philosophorum. Tamże w 1608 r. wydał go drukiem Jean Beguin, autor słynnego podręcznika Tyrocinium chymicum z 1610 r., wielokrotnie wznawianego wspólnie z dziełem Sędziwoja ${ }^{59}$. Wydaje się wszakże mało prawdopodobne, żeby Alstein dostał ten rękopis bezpośrednio od polskiego alchemika, który był bardzo ostrożny w nawiązywaniu kontaktów. Pośrednikiem był zapewne wspominany już wcześniej Jan Kapr z Kaprštejna, wieloletni znajomy Sędziwoja i członek kręgu Korálka. Od niego mógł też Alstein uzyskać sekretną recepturę, którą później w tajemnicy przekazywał innym ${ }^{60}$.

Z kolei Bodowski - przez Geliusa potraktowany jako postać niemal fikcyjna - był rzeczywiście wieloletnim zaufanym sługą Sędziwoja (źródłowo potwierdzonym od 1605 do 1628 r.), Grosschedel był zaś autorem dwóch publikacji alchemicznych oraz słynnego Calendarium naturale magicum perpetuum, rytowanego przez Matthäusa Meriana Starszego ${ }^{61}$. Niewiele wiadomo o jego życiorysie, ale urodził się w 1577 r. i pochodził zapewne z okolic Ratyzbony. W 1625 r. wpisał do album amicorum czeskiego alchemika Daniela Stolciusa parafrazę cytatu z dzieła Sędziwoja, co świadczy o uznawaniu go za autorytet, a być może i o znajomości osobistej. Zatem z pewnością mógł poznać Bodowskiego i od niego zdobyć przepis na Kamień Filozoficzny - już wówczas albo dopiero po śmierci polskiego filozofa.

${ }_{59}$ T.S. Patterson, Jean Beguin and his Tyrocinium chymicum, „Annals of Science” 1937, s. 243-298.

${ }^{60}$ R. Prinke, Zwodniczy ogród błędów..., dz. cyt., s. 502-504.

${ }_{61}$ Tenże, The Wroclaw codex of the Magical Calendar, „The Hermetic Journal” 1985, s. 26-29; C. Gilly, The rediscovery of the original of Großschedel's Calendarium Naturale Magicum Perpetuum, [w:] Magia, alchimia, scienza dal '400 al '700. L'influsso di Ermete Trismegisto / Magic, alchemy and science 15th-18th centuries. The influence of Hermes Trismegistus, C. Gilly, C. van Heertum (red.), Firenze 2003, vol. 1, s. 310-316. 
Ponieważ obie wersje receptury na „Tynkturę Sędziwoja” są bardzo podobne, a jednocześnie pochodzą ewidentnie $\mathrm{z}$ dwóch różnych źródeł zbliżonych do alchemika, zaś wersja podana przez Erbinäusa von Brandau też musi pochodzić od czeskich informatorów, to wydaje się niewątpliwe, że opisywany w nich proces był rzeczywiście tym samym, który Sędziwój pokazywał swoim zaufanym przyjaciołom. Nie oznacza to jednak, że jego interpretacja w kategoriach współczesnej chemii jest prosta i jednoznaczna. Terminologia $\mathrm{w}$ pismach alchemików i chymiatrów nie była ujednolicona ani nawet konsekwentna w ramach tekstów jednego autora. Co więcej, współcześni historycy również nie są zgodni co do przekładania poszczególnych terminów na pojęcia chemiczne. W przypadku omawianego procesu pojawiają się trzy substancje, które należy połączyć: sal nitri philosophorum, sal fixum i sal volatile. Roman Bugaj uznał dwie pierwsze za azotan potasu $\left(\mathrm{KNO}_{3}\right)$ i węglan potasu $\left(\mathrm{K}_{2} \mathrm{CO}_{3}\right)$, podczas gdy piszący niemal 30 lat później (i korespondujący z Bugajem) Gelius widział w nich azotan wapnia $\left(\mathrm{Ca}\left(\mathrm{NO}_{3}\right)_{2}\right)$ oraz chlorek sodu, czyli sól kuchenną $(\mathrm{NaCl})$. Obaj zgadzali się natomiast, że „sól lotna” to chlorek amonu, czyli salmiak $\left(\mathrm{NH}_{4} \mathrm{Cl}\right)^{62}$. Zbigniew Szydło, idąc za ustaleniami Bugaja, przeprowadził eksperyment, ale zamiast sal nitri, użył spiritus nitri, czyli kwas azotowy $\left(\mathrm{HNO}_{3}\right)$ i uzyskał mieszaninę, która rozpuściła płatek złota (menstruum universale), nie to jednak miało być rezultatem procesu Sędziwoja ${ }^{63}$. Według Bugaja, w odpowiednich warunkach mógł on pozwolić na otrzymanie mieszaniny tlenku rtęci ( $\mathrm{HgO})$ i kwasu chlorozłotowego $\left(\mathrm{H}\left[\mathrm{AuCl}_{4}\right]\right)$, natomiast zdaniem Geliusa mógł to być chlorozłocian srebra $\left(\mathrm{Ag}\left[\mathrm{AuCl}_{4}\right]\right)$. Wnioski te nie są bardzo rozbieżne, zważywszy na to, że zarówno warunki laboratoryjne, jak i szczegóły samej procedury są trudne do ustalenia i w znacznej mierze muszą być odgadywane przez współczesnych interpretatorów.

Do bardzo podobnych wniosków na temat składu Kamienia Filozofów - ale w oparciu o zupełnie inne teksty - doszedł już wcześniej południowoafrykański badacz Cornelis Johannes van Nieuwenburg (na ustaleniach którego opierał się Bugaj) ${ }^{64}$. Z innego traktatu alchemicznego podobny proces wywiódł nie tak dawno również Hereward

${ }^{62}$ R. Bugaj, Michał Sędziwój, s. 202-204; Gelius, Der „Processus universalis“ nach Michael Sendivogius, s. 184-186.

${ }^{63} \mathrm{Z}$. Szydło, The influence of the central nitre theory of Michael Sendivogius on the chemical philosophy of the seventeenth century, „Ambix” 1996, s. 80-98, przyp. 49.

${ }^{64}$ C.J. v. Nieuwenburg, The chemical composition of the Philosopher's Stone, „The South African Industrial Chemist” June 1963, s. 132-133. 
Tilton $^{65}$. Był to zachowany $\mathrm{w}$ rękopisie tekst Lux lucens in tenebris, którego autorstwo przypisał Heinrichowi Khunrathowi - z czym nie zgodził się Rudolf Werner Soukup, dowodząc, że to jedynie wersja anonimowego tekstu z 1514 r., wydanego w 1608 r. jako Lux in tenebris lucens $^{66}$. Tilton drobiazgowo zanalizował nie tylko ten tekst, ale także liczne wzmianki u innych alchemików, dochodząc do wniosku, że uzyskany w procedurze kwas chlorozłotowy, przechodzący w chlorek złota - nie w czystej postaci, ale raczej jako rodzaj wody królewskiej (aqua regia), zawierającej rozpuszczone w niej złoto - był następnie traktowany eterem jako reduktorem, $w$ rezultacie dając złoto koloidalne, czyli zawiesinę nanocząstek złota w eterze. Wnioski Tiltona zaakceptował również Soukup, rozwijając je dodatkowo w kategoriach chemicznych. Możliwe jest zatem, że receptura „Tynktury Sędziwoja” była znana już wcześniej i przekazywana w tajemnicy, a sporadycznie publikowana w bardzo zawoalowanych sformułowaniach, zrozumiałych jedynie dla już wtajemniczonych $\mathrm{w}$ jej praktyczne przeprowadzenie.

Eter dietylowy znany był (jako oleum dulci vitrioli) przynajmniej od początku XVI w., a eksperymenty z jego zastosowaniem opisywał też Paracelsus, nazywając go „embrioniczną siarką”, co może wiązać się z „Krwią Siarki” u Sędziwoja, tym bardziej że metodą otrzymywania eteru była destylacja kwasu siarkowego z alkoholem etylowym ${ }^{67}$. Jeśli „Tynktura Sędziwoja” istotnie była złotem koloidalnym zawieszonym w eterze, to polski alchemik mógł jej używać zarówno do pokazów transmutacji (według świadków smarował kawałki metalu jakimś płynem i potem podgrzewał, przez co eter odparowywał, a metal był pokrywany cienką warstwą złota), jak i leczenia. Eter powoduje euforię, co przy pewnych chorobach mogło dawać opisywane przez świadków efekty lecznicze. W XIX w. rozpowszechniło się przyjmowanie eteru w celach rekreacyjnych, praktykowane również w południowej Polsce (szczególnie wśród Łemków) i Czechach, a zwłaszcza

${ }^{65} \mathrm{H}$. Tilton, Of ether and colloidal gold: The making of a Philosophers' Stone, „Esoterica" 2007, s. 49-128.

${ }^{66}$ R.W. Soukup, Mercurius Solis: Hunting a mysterious alchemical substance, „International Workshop “On the Fringes of Alchemy”, Budapest 2010; R.W. Soukup, „Transforming the whole Corpus Solis into liquor irreducibilis.” Laboratory alchemy at the court of Emperor Rudolf II, [w:] Alchemy and Rudolf II..., dz. cyt., s. 205-228.

${ }^{67}$ W.R. Newman, The occult and the manifest among the alchemists, [w:] Tradition, transmission, transformation: Proceedings of two conferences on pre-modern science held at the University of Oklahoma, F.J. Ragep, S.P. Ragep, S.J. Livesey (red.), Leiden 1996, s. 189. 
na Śląsku ${ }^{68}$. Najpowszechniejszą formą konsumpcji eteru była (jest) „kropka”, czyli umieszczanie jednej kropli na języku i wdychanie oparów. Tak samo - według relacji Crolla - aplikował swoje cudowne lekarstwo Michał Sędziwój, podając pacjentom „unica illius Laticis gutta".

W podsumowaniu powyższych ustaleń można stwierdzić, że praktyka lekarska Michała Sędziwoja opierała się na dwóch filarach: klasycznej medycynie galenowskiej oraz tradycyjnej alchemii średniowiecznej. W obu przypadkach postulował empiryczną weryfikację wiedzy książkowej i aktywne poznawanie tajników przyrody, oparte na rozumieniu podstaw filozoficznych systemów wiedzy stworzonych przez dawnych mędrców. Sędziwój wyraźnie dystansował się natomiast od szkoły medyczno-chemicznej Paracelsusa, zapożyczając z niej tylko dwa pojęcia, którym nadał zresztą inne znaczenie. Skąpość źródeł $i$ ich enigmatyczna natura nie pozwala na jednoznaczne odtworzenie składu i procedury wytwarzania tynktury, którą Michał Sędziwój stosował - zgodnie w alchemiczną tradycją - zarówno przeprowadzając domniemane transmutacje metali, jak i dokonując spektakularnych uleczeń. Dotychczasowe próby rozwiązania tej zagadki polegały na teoretycznym rozważaniu różnych możliwych procesów chemicznych, co wymagałoby wszakże praktycznej weryfikacji. Podobnie jak w przypadku wielu innych receptur alchemicznych, stosowane w nich substancje dalekie były od chemicznej czystości i w związku z tym reakcje mogły przebiegać inaczej, jak to wykazał już dawno Lawrence Principe ${ }^{69}$. W ramach tego empirycznego nurtu badawczego nad historią alchemii grupa chemików i historyków nauki, kierowana przez Alexandra Krafta (Berlin) i Thomasa Moeniusa (Bazylea), rozpoczęła projekt zbadania „procesu uniwersalnego” Michała Sędziwoja. Obecnie trwa analiza licznych jego wersji, odnalezionych w źródłach drukowanych i rękopiśmiennych, a w niedługiej przyszłości rozpocznie się praktyczna weryfikacja. Rezultaty z pewnością będą interesujące i rzucą nowe światło na fascynującą i nadal enigmatyczną postać wielkiego polskiego alchemika.

${ }^{68}$ A. Zandberg, „Villages... reek of ether vapours”: Ether drinking in Silesia before 1939, „Medical History” 2010, s. 387-396.

${ }^{69}$ L.M. Principe, 'Chemical Translation' and the role of impurities in alchemy: Examples from Basil Valentine’s Triumph-Wagen, „Ambix” 1987, s. 21-30. 


\section{Summary}

Medicine in the activities and writings of Michael Sendivogius (1566-1636)

Michael Sendivogius, the Polish author of highly influential early modern alchemical treatises, is usually perceived as a typical chrysopoeian rather than a physician. Indeed, in his published texts he hardly mentioned medical applications of alchemy. There are, however, numerous scattered sources which testify to his medical practice and miraculous cures, witnessed by such well known physicians as Oswald Croll. The surviving Sendivogius's personal copy of Pharmacopoeia Augustana suggests he was well versed in the traditional Galenist pharmacy. The power of his elixir for prolongation of life was widely discussed and its chemical composition is hypothetically identified in the present paper.

Keywords: alchemy; early modern medicine; Sendivogius; Paracelsus; Croll 